\title{
Receptory dla glutaminianu w układzie dopaminowym - funkcjonalne znaczenie i rola w uczeniu się ze wzmocnieniem
}

\section{dr Przemysław Eligiusz Cieślak $^{\square}$}

Zakład Neurofizjologii i Chronobiologii, Instytut Zoologii i Badań Biomedycznych, Uniwersytet Jagielloński, Gronostajowa 9, 30-387, Kraków

https://doi.org/10.18388/pb.2021_395

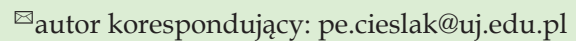

Słowa kluczowe: dopamina, receptor NMDA receptor mGluR5, uczenie się ze wzmocnieniem, motywacja

Wykaz skrótów: GABA - kwas Y-aminomasłowy; LTD - długotrwałe osłabienie synaptyczne; LTP - długotrwałe wzmocnienie synaptyczne; mGluR5 - metabotropowy receptor dla glutaminianu mGluR5; NMDA N-metylo-D-asparaginian

\section{STRESZCZENIE}

Neurony dopaminergiczne śródmózgowia i neurony dopaminoceptywne prążkowia mają kluczowe znaczenie dla regulacji procesu uczenia się ze wzmocnieniem i motywacji do poszukiwania nagród. Aktywność oraz plastyczność tych neuronów jest $\mathrm{W}$ znacznej mierze zależna od pobudzającej transmisji glutaminianergicznej. W szczególności istotną rolę odgrywają receptory N-metylo-D-asparaginowe (NMDA) oraz metabotropowe receptory dla glutaminianu z grupy I, zwłaszcza mGluR5. W niniejszym artykule omówiono znaczenie aktywacji tych receptorów dla regulacji aktywności fazowej neuronów dopaminergicznych i plastyczności neuronów dopaminoceptywnych prążkowia. Opierając się na badaniach przeprowadzonych na zwierzętach z komórkowo specyficzną inaktywacją receptorów glutaminianu w układzie dopaminowym, przedstawiono również konsekwencje zaburzenia przekazywania sygnału zależnego od tych receptorów dla procesu uczenia się ze wzmocnieniem i motywacji do poszukiwania nagród. Omówione w artykule mechanizmy mogą mieć istotne znaczenie dla zrozumienia neuronalnego podłoża objawów towarzyszących chorobom psychicznym takim jak depresja, schizofrenia czy uzależnienia.

\section{ROLA UKŁADU DOPAMINOWEGO W UCZENIU SIĘ ZE WZMOCNIENIEM I MOTYWACJI DO POSZUKIWANIA NAGRÓD}

\section{ANATOMIA UKŁADU DOPAMINOWEGO ŚRÓDMÓZGOWIA}

Neurony dopaminergiczne to komórki wykorzystujące dopaminę jako neuroprzekaźnik, a więc posiadające zdolność syntezy oraz uwalniania dopaminy. Dlatego też, markerem biochemicznym wykorzystywanym do identyfikacji komórek dopaminergicznych jest ekspresja hydroksylazy tyrozynowej, enzymu niezbędnego do syntezy dopaminy [1-3]. Ze względu jednak na obecność tego enzymu w komórkach nie-dopaminowych, bardziej selektywnym znacznikiem neuronów dopaminergicznych jest ekspresja transportera dopaminy, odpowiadającego za wychwyt zwrotny neuroprzekaźnika. Ekspresja transportera wyrażana jest niemal wyłącznie przez komórki dopaminergiczne śródmózgowia [4]. Ciała tych komórek zgrupowane są w obszarze dwóch przylegających do siebie jąder, części zbitej istoty czarnej i polu brzusznym nakrywki, a ich lokalizacja odpowiada grupie A9 i A10 według nomenklatury Dahlström i Fuxe [5].

Głównym celem projekcji neuronów dopaminergicznych śródmózgowia jest prążkowie (Ryc. 1A) [1,6-8]. Zakończenia neuronów dopaminergicznych istoty czarnej znajdują się w grzbietowym prążkowiu, tworzonym przez jądro ogoniaste i skorupę. Z kolei zakończenia neuronów wychodzących z pola brzusznego nakrywki docierają do brzusznego prążkowia, tworzonego przez jądro półleżące. Neurony istoty czarnej unerwiające grzbietowe prążkowie, odgrywają kluczową rolę w kontroli motorycznej i uczeniu instrumentalnym. Natomiast neurony pola brzusznego nakrywki unerwiające jądro półleżące, mają istotne znaczenie dla przetwarzania informacji o nagrodzie, regulacji motywacji i uczenia asocjacyjnego. Oprócz połączeń z prążkowiem, neurony dopaminergiczne śródmózgowia tworzą połączenia z przyśrodkową korą przedczołową i podstawno-bocznym jądrem migdałowatym, zapewniając tym samym modulacje procesów poznawczych i emocji. Warto więc zaznaczyć, że neurony dopaminergiczne śródmózgowia stanowią heterogeniczną populację, zbudowaną z podgrup komórek, które w zależności od rodzaju tworzonych połączeń i właściwości fizjologicznych mogą pełnić wyspecjalizowane funkcje behawioralne $[2,9,10]$.

Charakterystyczną cechą neuronów dopaminergicznych śródmózgowia jest generowanie przez nie dwóch trybów aktywności elektrycznej, które przekła- 
dają się na różne uwalnianie neuroprzekaźnika [11,12]. Bazowa aktywność elektryczna komórek dopaminergicznych in vivo charakteryzuje się niską częstotliwością wyładowań $(<10 \mathrm{~Hz})$ w postaci pojedynczych, mniej lub bardziej regularnie generowanych potencjałów czynnościowych, co skutkuje powolnym uwalnianiem dopaminy, ten tryb nazywany jest trybem tonicznym. Krótkotrwałe (<500 ms) serie trzech lub więcej potencjałów czynnościowych wygenerowanych z wysoką częstotliwością (>10 Hz) oraz następujący po nich przejściowy, duży wzrost zewnątrzkomórkowego stężenia dopaminy określane jest mianem trybu fazowego. Głównym regulatorem aktywności fazowej neuronów dopaminergicznych śródmózgowia są wejścia glutaminianergiczne i cholinergiczne $\mathrm{z}$ jąder nakrywki mostu, jądra konarowo-mostowego i grzbietowo-bocznego [13-15]. Oprócz fazowych wzrostów, aktywność elektryczna neuronów dopaminergicznych może również ulegać chwilowym przyhamowaniom. Występowanie tego rodzaju pauz w generowaniu potencjałów czynnościowych związane jest z hamowaniem zależnym od kwasu $\mathrm{\gamma}$-aminomasłowego (GABA). Głównym źródłem GABA uwalnianego na neurony dopaminergiczne jest unerwienie z brzusznej części gałki bladej, przednio-przyśrodkowego jądra nakrywki oraz lokalnych neuronów GABA-ergicznych w polu brzusznym nakrywki i części zbitej istoty czarnej [11]. Zarówno fazowa aktywacja neuronów dopaminergicznych, jak i pauzy mają istotne znaczenie dla regulacji mechanizmu uczenia się ze wzmocnieniem $[8,16]$.

Dopamina uwalniana z zakończeń komórek śródmózgowia wiąże się do dwóch typów receptorów dopaminowych, D1 i D2, a neurony postsynaptyczne na których znajdują się te receptory nazywane są potocznie neuronami dopaminoceptywnymi. Receptory D1 i D2 są receptorami metabotropowymi sprzężonymi odpowiednio z białkami $\mathrm{Ga}_{\text {s/olf }} \mathrm{i} \mathrm{Ga}_{\mathrm{i} / \mathrm{o}}$ [17]. Dzięki temu, w zależności od typu receptora obecnego po stronie postsynaptycznej, dopamina pobudza lub hamuje aktywność neuronalną. Warto zaznaczyć, że dopamina pełni rolę modulacyjną, a efekt pobudzenia/hamowania
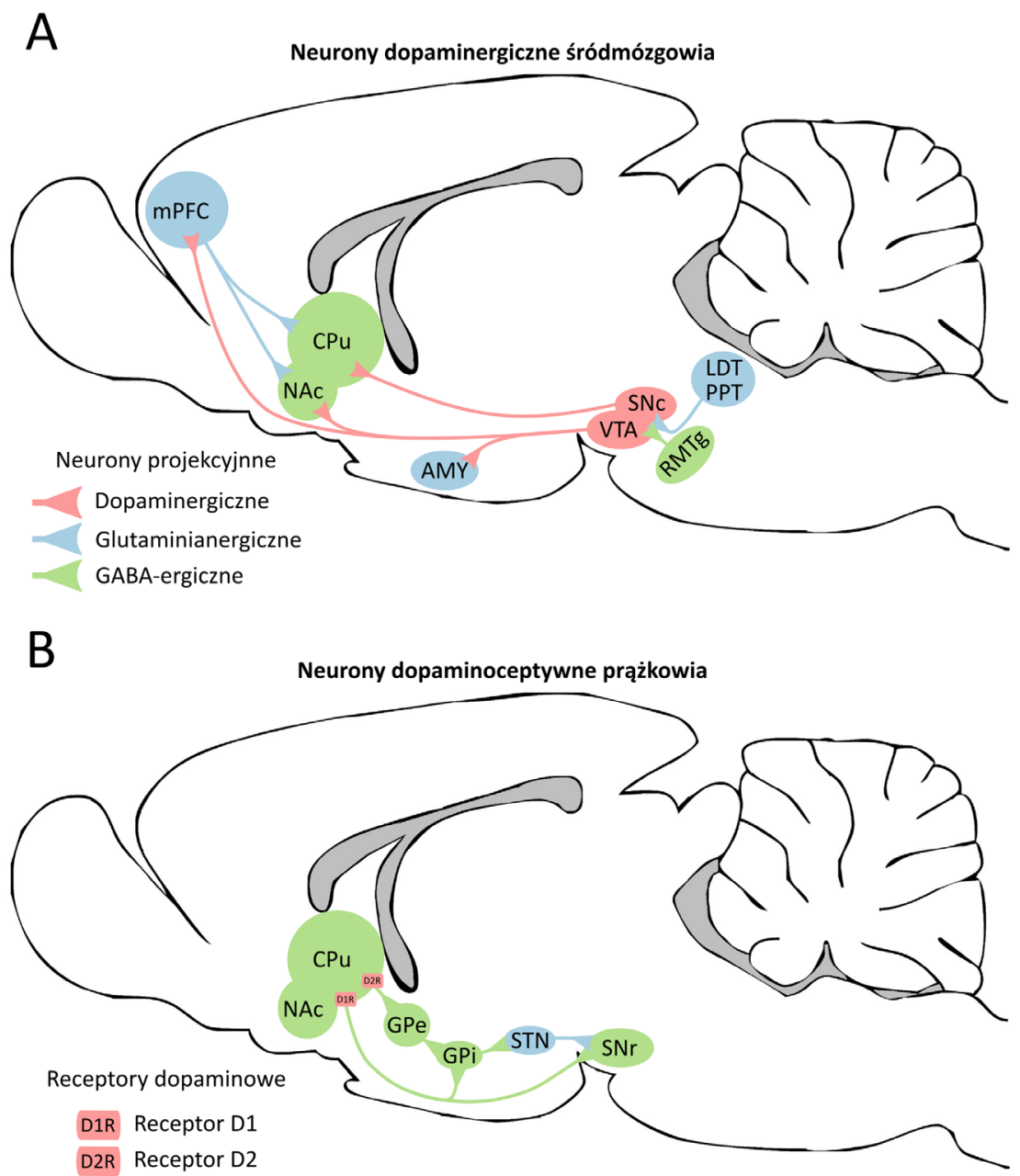

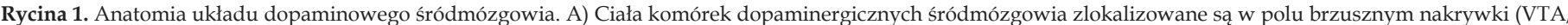

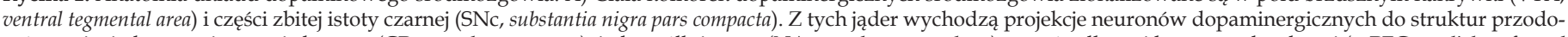

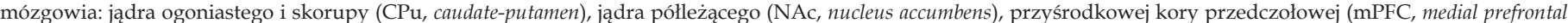

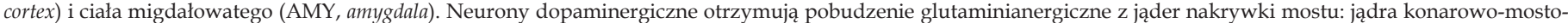

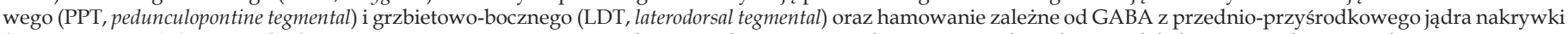

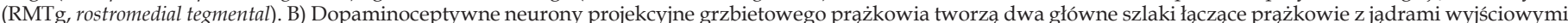

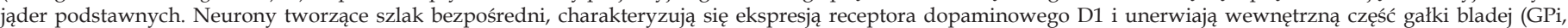

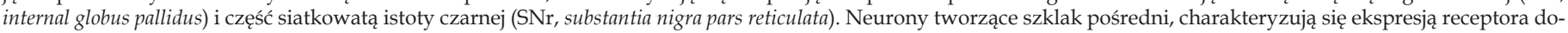

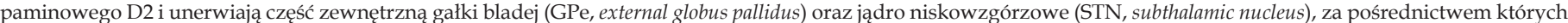
sygnały są przekazywane do jąder wyjściowych. 
jest konsekwencją zmian we wrażliwości neuronu postsynaptycznego na pobudzenie. Postsynaptyczne receptory D1 mają niskie powinowactwo do dopaminy, a receptory D2 wysokie. Dlatego też uważa się, że receptory D2 aktywowane są podczas bazowej, tonicznej aktywności neuronów dopaminergicznych, natomiast aktywacja receptorów D1 ma miejsce podczas fazowej aktywności neuronów dopaminergicznych $[18,19]$. Przerwy w aktywności neuronów dopaminergicznych powodują dezaktywację obu typów receptorów [18]. Receptory D2 pełnią również rolę autoreceptorów, które zapewniają zwrotne hamowanie aktywności neuronów dopaminergicznych. Receptory obu typów są obecne w dużej ilości w jądrach podstawnych, gdzie zlokalizowane są na średnich neuronach kolczystych [20,21]. Te GABA-ergiczne neurony projekcyjne tworzą dwa główne szlaki łączące prążkowie z jądrami wyjściowymi jąder podstawnych, wewnętrzną częścią gałki bladej i częścią siatkowatą istoty czarnej (Ryc. 1B). Neurony prążkowia tworzące tzw. szlak bezpośredni, unerwiają jądra wyjściowe jąder podstawnych, natomiast neurony tworzące tzw. szlak pośredni, unerwiają część zewnętrzną gałki bladej oraz jądro niskowzgórzowe, za pośrednictwem których sygnały są przekazywane do jąder wyjściowych. Charakterystyczną cechą tych połączeń jest selektywna ekspresja receptorów D1 albo D2. Neurony tworzące szlak bezpośredni charakteryzuje ekspresja receptora D1, a neurony tworzące szlak pośredni receptora D2 [22-24]. Dlatego też, neurony tworzące drogę bezpośrednią nazywa się umownie "neuronami D1", a neurony tworzące drogę pośrednią "neuronami D2". Klasyczny pogląd na funkcję obu szlaków zakłada, że drogi te zaangażowane są odpowiednio w inicjację i hamowanie ruchu. Współcześnie uważa się również, że neurony D1 i D2 odgrywają istotną rolę w uczeniu się ze wzmocnieniem $[25,26]$.

\section{UCZENIE SIĘ ZE WZMOCNIENIEM}

W serii eksperymentów przeprowadzonych na początku lat 90 ubiegłego wieku Wolfram Schultz i jego współpracownicy zaobserwowali, że neurony dopaminergiczne śródmózgowia u naczelnych odpowiadają fazową aktywacją na nieoczekiwane dostarczenie zwierzęciu słodkiego płynu lub jedzenia (przegląd tych doświadczeń został omówiony w [8]). Gdy dostarczenie nagrody poprzedzone było prezentacją bodźca zapowiadającego przyszłe wzmocnienie neurony dopaminergiczne zaczynały reagować wzrostem aktywności fazowej na pojawienie się owego bodźca, ale nie samej nagrody. Natomiast, gdy spodziewana nagroda była pominięta neurony dopaminergiczne odpowiadały chwilową pauzą aktywności elektrycznej. Opierając się na obserwacjach Schultza, Read Montague i Peter Dayan zasugerowali, że aktywność neuronów dopaminergicznych może kodować informację o rozbieżności pomiędzy wynikiem oczekiwanym a wynikiem uzyskanym, tj. błędzie przewidywania nagrody $[27,28]$. Ów błąd sygnalizowany przez neurony dopaminergiczne umożliwia aktualizację posiadanej wiedzy na temat wartości działań prowadzących do uzyskania wzmocnienia i oczekiwanej przyszłej konsekwencji owych działań. Późniejsze badania wykazały również, że aktywność neuronów dopaminergicznych modulowana jest przez prawdopodobieństwo uzyskania nagrody i jej wielkość $[29,30]$. Obserwacje te stanowiły podstawę do przypuszczenia, że neurony dopaminergiczne kodują informacje o ryzyku i oczekiwanej wartości nagród - zmiennych ekonomicznych istotnych dla procesu podejmowania decyzji opartych o wartość.

Dowodem na bezpośredni związek pomiędzy aktywnością fazową neuronów dopaminergicznych a uczeniem się ze wzmocnieniem są obserwacje pokazujące, że stymulacja neuronów dopaminergicznych śródmózgowia prowadzi do wzmocnienia i powtarzania działań powiązanych ze stymulacją [31-33]. Proponowanym mechanizmem działania dopaminy jest jej wpływ na modyfikację plastyczności synaps korowo-prążkowiowych [34-36]. Uważa się, że fazowe uwalnianie dopaminy towarzyszące działaniu, które doprowadziło do nieoczekiwanego uzyskania nagrody, prowadzi do wzmocnienia połączeń synaptycznych w neuronach aktywnych podczas tego zdarzenia, zwiększając tym samym prawdopodobieństwo jego powtórzenia w przyszłości. Przykładem stanowiącym potwierdzenie tej hipotezy jest obserwacja, że stymulacja neuronów dopaminergicznych istoty czarnej, w sposób zależny od aktywacji receptora D1, wzmacnia połączenia synaptyczne między korą a neuronami projekcyjnymi prążkowia, a siła tego wzmocnienia dodatnio koreluje z szybkością uczenia się instrumentalnej reakcji samodrażnienia mózgu [37]. Późniejsze badania wykazały również, że bezpośrednia aktywacja neuronów D1 jest wystarczająca do wywołania długotrwałego wzmocnienia zachowania w sposób niezależny od aktywacji samych receptorów dopaminowych [25]. Co więcej, w sytuacji wyboru między konkurencyjnymi kursami działania, aktywacja neuronów D1 lub D2 w grzbietowym prążkowiu zmienia oczekiwaną wartość dostępnych działań i wpływała na dokonanie przyszłego wyboru [26]. Obserwacje te są zgodne z poglądem, że prążkowie koduje informację o oczekiwanej wartości działań, a dopamina zapewnia sygnał niezbędny do jej aktualizacji $[37,38]$. Z doświadczeń tych wynika więc, że aktywność fazowa neuronów dopaminergicznych oraz plastyczność neuronów dopaminoceptywnych prążkowia stanowi neuronalny substrat uczenia się ze wzmocnieniem i podejmowania decyzji o wyborze działań o największej oczekiwanej wartości.

W badaniach na ludziach wykorzystujących funkcjonalne obrazowanie mózgu wykazano, że sygnał zależny od poziomu natlenienia krwi rejestrowany w obszarze prążkowia oraz śródmózgowia koduje informację o błędzie przewidywania nagrody i jej oczekiwanej wartości [39-43]. Co więcej, w badaniu, w którym osobom badanym podawano prekursor dopaminy lewodopę oraz antagonistę receptorów dopaminowych D2 haloperidol, wykazano, że leki te odpowiednio zwiększają lub zmniejszają prawdopodobieństwo wyboru częściej nagradzanego działania [42]. Ciekawym wnioskiem z tych badań jest to, że u ludzi nagroda pieniężna wywołuje taki sam stopień aktywacji obszarów mózgu zaangażowanych w ocenę działania co nagroda naturalna. Oznacza to, że u ludzi układ dopaminowy odgrywa rolę $\mathrm{w}$ podejmowaniu decyzji ekonomicznych. Interpretacja wyników tych badań nie jest wprawdzie wolna od ograniczeń, ponieważ sygnał zależny od poziomu natlenienia krwi nie odzwierciedla rzeczywistej aktywności układu dopaminowego. Niemniej jednak, obserwacje te wydają się potwierdzać, że neuronalny substrat kodowania błędu przewidy- 
wania nagrody i uczenia się ze wzmocnieniem jest zakonserwowany w mózgach ssaków i ma istotne znaczenie dla podejmowania decyzji o znaczeniu adaptacyjnym.

Mając na uwadze rolę jaką układ dopaminowy odgrywa w kodowaniu informacji o nagrodzie przypuszcza się, że w przebiegu wielu chorób neurologicznych i psychiatrycznych może dochodzić do rozregulowania mechanizmów uczenia się ze wzmocnieniem. Ciekawe w tym kontekście są badania prowadzone na pacjentach z chorobą Parkinsona, u których w wyniku procesu chorobowego dochodzi do uszkodzenia neuronów dopaminergicznych i znacznego obniżenia uwalniania dopaminy w jądrach podstawnych. Pacjenci ci charakteryzują się wolniejszym uczeniem na podstawie konsekwencji dokonywanych wyborów oraz skłonnością do kierowania się negatywnymi, aniżeli pozytywnymi informacjami zwrotnymi $[44,45]$. Podanie pacjentom leków nasilających transmisję dopaminergiczną (np. lewodopy), przywraca wrażliwość na pozytywne informacje zwrotne i zwiększa szybkość uczenia się na podstawie pozytywnego wyniku podejmowanych działań. Zaburzenie kodowania informacji o nagrodzie i procesu uczenia się ze wzmocnieniem zaobserwowano także u osób cierpiących na inne choroby powiązane z dysfunkcją układu dopaminowego - depresję, schizofrenię czy uzależniania [46,47]. Z przytoczonych badań wynika więc, że zaburzenie funkcji układu dopaminowego prowadzić może do zaburzenia procesów uczenia się opartego o nagrodę.

\section{MOTYWACJA DO POSZUKIWANIA NAGRÓD}

Dopamina wpływa nie tylko na wybór kierunku działania, ale również na proces jego inicjacji i podtrzymania [48]. Obserwacje te wspierane są przez doświadczenia pokazujące, iż wzrost zewnątrzkomórkowego stężenia dopaminy w brzusznym prążkowiu poprzedza moment rozpoczęcia działania [31,49,50], zwłaszcza gdy działanie to charakteryzuje się wysokim wigorem [51]. Ponadto, doświadczenia farmakologiczne wskazują na to, że zablokowanie receptorów dopaminowych w obszarze brzusznego prążkowa wydłuża czas do zaangażowania się w wykonanie działania nakierowanego na zdobycie nagrody i obniża skłonność do wyboru działania wymagającego wykonania większego wysiłku [52-54]. Z badań tych wynika również, że zachowanie związane $\mathrm{z}$ samym celem działania, czyli np. podejście do podajnika, do którego dostarczana jest nagroda oraz jej konsumpcja, pozostają niezmienione. Oznacza to, że dopamina reguluje przede wszystkim fazę inicjacji działania i wydatkowania wysiłku, odpowiadając tym samym za aktywacyjny aspekt motywacji $[48,55]$.

Także u ludzi zaobserwowano związek pomiędzy aktywacją układu dopaminowego a oceną kosztu działania i podejmowaniem decyzji o wyborze działania związanego z wysiłkiem [56-58]. Co więcej, w badaniach, w których podawano ludziom lewodopę obserwowano wzrost wigoru działania nakierowanego na pozyskanie nagrody $[59,60]$. U osób z chorobą Parkinsona oraz depresją obserwowano natomiast mniejszą skłonność do wyboru działania związanego z wysiłkiem oraz obniżenie wigoru [61,62]. W przypadku osób chorych na Parkinsona, nasilenie transmisji dopaminergicznej wywołane podaniem lewodopy, odwracało deficyty motywacyjne [61]. Z badań tych wynika więc, że dopamina pełni istotną rolę $\mathrm{w}$ ocenie kosztu działania i regulacji wydatkowania wysiłku.

Zjawiskiem łączącym wpływ dopaminy na uczenie się ze wzmocnieniem i motywację jest proces przypisania wartości motywacyjnej bodźcom skojarzonym z nagrodą [6365]. W wyniku tego procesu bodźce skojarzone $\mathrm{z}$ nagrodą uzyskują kontrolę nad zachowaniem, nasilając zachowania nakierowane na jej zdobycie i stając się pożądanymi na równi z samą nagrodą. Przykładem tego jest zachowanie obserwowane u gryzoni, które oprócz eksploracji miejsca, do którego dostarczana jest nagroda, tzw. śledzenie celu (ang. goal-tracking) eksplorują również miejsce, gdzie prezentowany jest bodziec przewidujący nagrodę, tzw. śledzenie znaku (ang. sign-tracking). Zachowaniu nakierowanemu na śledzenie znaku towarzyszy nasilone fazowe uwalnianie dopaminy w brzusznym prążkowiu [65]. Co więcej, zachowanie nakierowane na śledzenie znaku, ale nie zachowanie nakierowana na śledzenie celu, hamowane jest przez blokadę receptorów dopaminowych $[65,66]$. Oznacza to, że podczas uczenia asocjacyjnego fazowa aktywacja neuronów dopaminergicznych umożliwia przypisanie wartości motywacyjnej bodźcom przewidującym nagrodę.

\section{ZALEŻNA OD GLUTAMINIANU REGULACJA AKTYWNOŚCI NEURONÓW DOPAMINERGICZNYCH I PLASTYCZNOŚCI NEURONÓW DOPAMINOCEPTYWNYCH PRĄŻKOWIA}

\section{AKTYWNOŚĆ NEURONÓW \\ DOPAMINERGICZNYCH ŚRÓDMÓZGOWIA}

Zgodnie z hipotezą kodowania błędu przewidywania nagrody neurony dopaminergiczne śródmózgowia odpowiadają aktywacją o charakterze fazowym na dostarczenie zwierzęciu niespodziewanej nagrody lub nagrody większej niż oczekiwana. Uwalniana podczas tego zdarzenia dopamina moduluje plastyczność neuronów dopaminoceptywnych prążkowia, które kodują wartość dokonanego wyboru. Większość wiedzy na temat mechanizmu generowania aktywności fazowej przez neurony dopaminergiczne oraz związanej z tym plastyczności synaptycznej neuronów prążkowa pochodzi z doświadczeń wykonanych w anestezji lub na preparatach ex vivo. U zwierząt uśpionych obserwuje się bowiem występowanie spontanicznych epizodów aktywności fazowej, które nie różnią się czasem trwania czy częstotliwością wyładowań od epizodów aktywności związanych z prezentacją nagrody [11,67]. Dlatego też uważa się, że mechanizm powstawania aktywności fazowej u uśpionych oraz przytomnych zwierząt jest taki sam.

Głównym regulatorem aktywności fazowej neuronów dopaminergicznych śródmózgowia są receptory NMDA, jonotropowe receptory dla glutaminianu, aktywowane przez kwas N-metylo-D asparaginowy (Ryc. 2). Podanie kwasu N-metylo-D-asparaginowego za pomoca jontoforezy prowadzi do gwałtownego wzrostu wyładowań o charakterze fazowym, a farmakologiczna blokada receptorów NMDA zaburza generowanie spontanicznych epizodów aktywności fazowej [68,69]. Zahamowaniu zależnej od receptora NMDA aktywności elektrycznej neuronów dopaminergicznych towarzyszy także zahamowanie fazowego 
uwalniania dopaminy $\mathrm{w}$ brzusznym prążkowiu [70,71]. Na podstawie przytoczonych badań wysunięto przypuszczenie, że przekazywanie sygnału, zależne od receptorów dla glutaminianu, może pełnić kluczową rolę w sygnalizowaniu błędu przewidywania nagrody. Za hipotezą tą przemawiają badania, w których wykorzystano zwierzęta $\mathrm{z}$ genetyczną inaktywacją receptorów dla glutaminianu $\mathrm{w}$ neuronach układu dopaminowego. Badania te wykazały, że usunięcie funkcjonalnych receptorów NMDA z neuronów dopaminergicznych hamuje aktywność fazową i osłabia fazowe uwalnianie dopaminy $\mathrm{w}$ prążkowiu [72-74]. Niemniej, wadą dotychczas stosowanych modeli zwierzęcych było to, że mutacja zachodziła na wczesnym etapie rozwoju co wiązało się z występowaniem zmian kompensacyjnych, np.: wzrostem spontanicznej aktywności neuronów dopaminergicznych śródmózgowia [75,76]. Rozwiązaniem tego problemu było wytworzenie zwierząt $\mathrm{z}$ indukowalnym wariantem rekombinazy Cre (CreERT2), który umożliwiał indukcję mutacji w dorosłości [75]. Badania elektrofizjologiczne na tych zwierzętach wykazały, że indukcja mutacji $\mathrm{u}$ dorosłych myszy prowadzi do całkowitego zahamowania zależnej od receptora NMDA aktywności fazowej neuronów dopaminergicznych śródmózgowia oraz obniżenia poziomu ich spontanicznej aktywności [77].

\section{PLASTYCZNOŚĆ NEURONÓW \\ DOPAMINOCEPTYWNYCH PRĄŻKOWIA}

Oprócz roli w kontrolowaniu aktywności neuronów dopaminergicznych, receptory dla glutaminianu mają również istotne znaczenie dla regulacji plastyczności synaps korowo-prążkowiowych (Ryc. 2), która może odpowiadać za aktualizację informacji o wartości działania przez neurony dopaminoceptywne prążkowia $[34,35,78,79]$. Z badań, w których analizowano zjawisko długotrwałego wzmocnienia (LTP) oraz osłabienia (LTD) synaptycznego wynika, że aktywacja receptorów NMDA zlokalizowanych na neuronach prążkowia, wyrażających ekspresję receptora D1 (czyli aktywowanych przez fazowo uwalnianą dopaminę), jest konieczna dla wywołania LTP oraz indukcji plastyczności strukturalnej [78,79]. Aktywacja metabotropowych receptorów dla glutaminianu z grupy I, zwłaszcza mGluR5, jest z kolei kluczowa dla wywołania LTD [78].

W badaniach wykorzystujących zwierzęta modyfikowane genetycznie wykazano, że utrata receptorów NMDA w neuronach GABA-ergicznych prążkowia powoduje zmiany w morfologii (mniejsze ciała komórkowe, krótsze dendryty) i aktywności tych neuronów oraz prowadzi do poważnego upośledzenia postnatalnego rozwoju zwierząt, co utrudnia

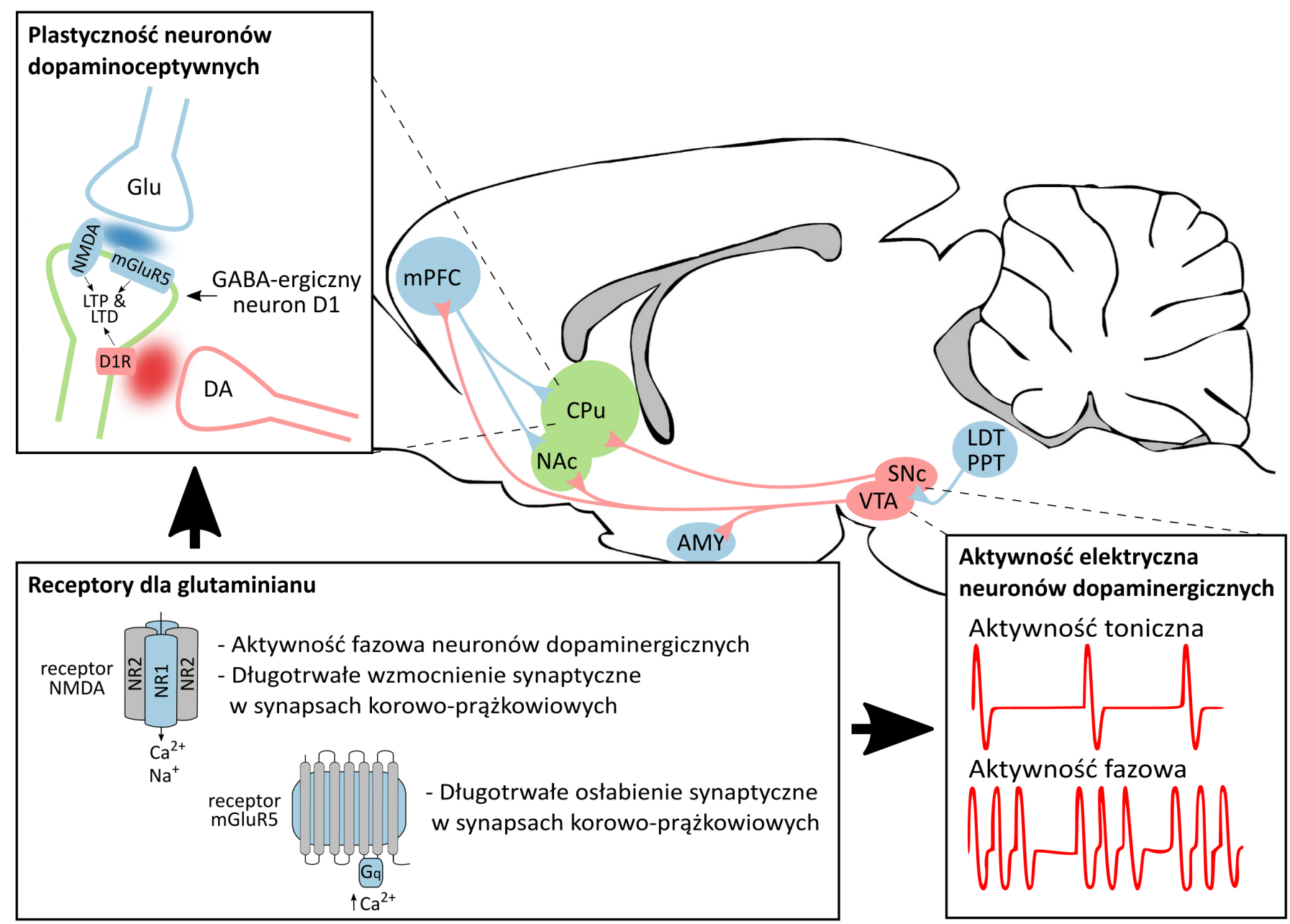

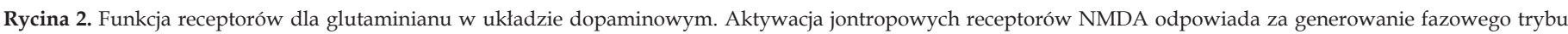

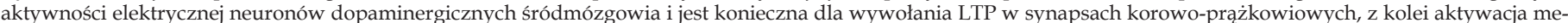
tabotropowych receptorów z grupy I, mGluR5, jest kluczowa dla wywołania LTD. 
wykorzystanie tych zwierząt do badań behawioralnych $[80,81]$. Całkiem niedawno wytworzono jednak myszy z indukowalnym wariantem mutacji, selektywnie w neuronach D1 [82]. Zwierzęta te rozwijają się normalnie, a inaktywacja receptorów NMDA następuje w dorosłości. Badania elektrofizjologiczne wykazały, iż konsekwencją indukcji mutacji u tych myszy jest utrata zależnej od receptora NMDA komponenty pobudzającego prądu postsynaptycznego oraz osłabienie LTP w jądrze półleżącym [82]. W przypad$\mathrm{ku}$ zwierząt $\mathrm{z}$ inaktywacją metabotropowych receptorów dla glutaminianu z grupy I, dostępne są zwierzęta z utratą receptora mGluR5, selektywnie w neuronach D1 [83]. Pomimo działania mutacji na wczesnym etapie rozwoju u myszy nie obserwuje się niepożądanych zmian $\mathrm{w}$ rozwoju postnatalnym [84]. W wyniku mutacji ilość transkryptu mGluR5 w prążkowiu zredukowana jest do $\sim 40 \%$, czemu towarzyszy $\sim 50 \%$ spadek ilości białka mGluR5 [83]. Elektrofizjologiczne konsekwencje utraty receptora mGluR5 w neuronach D1 dotychczas nie są znane. Mając jednak na uwadze znaczenie przekazywania sygnału zależnego od tego receptora dla powstawania LTD można przypuszczać, że właśnie ta forma plastyczności synaptycznej może być u tych zwierząt zaburzona.

\section{WPLYW KOMÓRKOWO SPECYFICZNEJ INAKTYWACJI RECEPTORÓW GLUTAMINIANU W UKŁADZIE DOPAMINOWYM NA UCZENIE SIĘ ZE WZMOCNIENIEM I MOTYWACJĘ}

\section{UCZENIE SIĘ ZE WZMOCNIENIEM}

Z przytoczonych badań wynika, że aktywność fazowa neuronów dopaminergicznych śródmózgowia sygnalizuje błąd przewidywania nagrody, co ma kluczowe znaczenie dla zajścia procesu uczenia się opartego na wzmocnieniu oraz że wykorzystanie zwierząt z selektywną inaktywacją receptorów dla glutaminianu stanowi cenne narzędzie do badania zachowań zależnych od fazowo uwalnianej dopaminy i związanej z tym plastyczności synaptycznej neuronów dopaminoceptywnych. W badaniach behawioralnych, w których badano proces uczenia się ze wzmocnieniem zaobserwowano, że myszy pozbawione receptorów NMDA w neuronach dopaminergicznych wolniej uczyły się na podstawie konsekwencji dokonywanych wyborów, a dokonane przez nie wybory miały losowy charakter i nie rozróżniały one wartości ich następstw [85]. Dodatkowo, zwierzęta te były mniej skłonne do powtórzenia poprzednio nagrodzonego wyboru. Niemniej jednak, w końcowej fazie eksperymentu zwierzęta z mutacją wybierały bardziej korzystną opcję równie często jak zwierzęta kontrolne co oznacza, iż zahamowanie zależnej od receptora NMDA aktywności fazowej neuronów dopaminergicznych spowolniło proces uczenia się na podstawie konsekwencji własnych działań, ale nie uniemożliwiło zaistnienia procesu uczenia się. Podobne zjawisko obserwowano wcześniej u zwierząt z konstytutywną mutacją, u których zauważono odroczony efekt nabierania wprawy w wykonaniu testów instrumentalnych wzmacnianych nagrodą $[72,86]$. Zatem, zależna od receptora NMDA aktywność fazowa neuronów dopaminergicznych wydaje się mieć istotne znaczenie dla szybkości i wydajności procesu uczenia się ze wzmocnieniem, ale nie jest ona niezbędna dla zaistnienia samego procesu uczenia się.
Podobnie utrata receptorów mGluR5 w neuronach wyrażających ekspresję receptora D1 powodowała, iż zwierzęta z mutacją były mniej skłonne do powtórzenia poprzednio nagrodzonego wyboru oraz mniej skłonne do wybierania częściej nagradzanej opcji [85]. Zjawisko to tłumaczyć można zaburzeniem zdolności do aktualizacji wartości działania przez neurony prążkowia. W wyniku zaburzenia tego procesu zwierzę jest mniej wrażliwe na pozytywne wzmocnienie, a dokonywane przez nie wybory charakteryzują się większą losowością. Nie zaobserwowano jednak takiego efektu u zwierząt z indukowalną inaktywacją receptorów NMDA, co jest po części nieoczekiwane, ponieważ aktywacja receptorów NMDA w prążkowiu ma istotne znaczenie dla uczenia się na podstawie konsekwencji podejmowanych działań [87]. Potencjalnym wyjaśnieniem tego zjawiska może być różnica w ekspresji mutacji u obu szczepów. Wcześniejsze badania wykazały bowiem, iż ekspresja transgenu u myszy pozbawionych receptora mGluR5 jest wydajna w obszarze grzbietowego jak i brzusznego prążkowia [83,84]. Z kolei u myszy pozbawionych receptora NMDA mutacja jest skuteczna przede wszystkim w brzusznym prążkowiu [82]. Różnica w wydajności mutacji ma o tyle istotne znaczenie, iż brzuszna część prążkowia zaangażowana jest w proces kojarzenia bodźca z wynikiem, podczas gdy grzbietowe prążkowie odgrywa kluczową rolę w uczeniu się na podstawie konsekwencji dokonanych wyborów [87-89]. Można więc przypuszczać, że modyfikacja plastyczności synaptycznej w neuronach dopaminoceptywnych grzbietowego, lecz nie brzusznego prążkowia, ma kluczowe znaczenie dla aktualizowania wartości działania, a gdy proces ten ulega zaburzeniu, jak ma to miejsce w przypadku zwierząt z utratą receptora mGluR5, skutkuje to większą losowością dokonywanych wyborów.

\section{PRZYPISANIE WARTOŚCI MOTYWACYJNEJ BODŹCOM I MOTYWACJA DO POSZUKIWANIA NAGRÓD}

$W$ badaniach nad mechanizmem uczenia się asocjacyjnego zaobserwowano, iż myszy pozbawione w dorosłości receptorów NMDA w neuronach dopaminergicznych, uczą się wartości predykcyjnej bodźców prezentowanych w tracie eksperymentu i poprawnie reagują na bodziec przewidujący dostarczenie nagrody [90]. Wynik ten jest zgodny z obserwacjami poczynionymi w badaniach, w których wykorzystano zwierzęta z konstytutywną mutacją receptorów NMDA [73,86], co potwierdza, iż zahamowanie zależnej od receptora NMDA aktywności fazowej neuronów dopaminergicznych nie zaburza uczenia się asocjacyjnego i wykonania uwarunkowanej reakcji na bodziec. Interesującym jednak jest, że zachowanie związane z eksploracją podajnika, do którego dostarczana była nagroda, było nasilone w grupie zwierząt kontrolnych, ale nie u zwierząt $\mathrm{z}$ mutacją. Co więcej, u części zwierząt kontrolnych można było zaobserwować dużą skłonność do samodostarczania bodźca skojarzonego z nagrodą, nawet jeżeli nie towarzyszyła temu prezentacja nagrody. Oznacza to, że dla zwierząt kontrolnych, ale nie dla myszy z mutacją, sam bodziec zyskał wartość nagradzającą i działał jako warunkowe wzmocnienie. Obserwacje te są zgodne $\mathrm{z}$ doniesieniami wskazującymi na to, że doraźne zablokowanie receptorów NMDA w polu brzusznym nakrywki blokuje warunkowe wzmocnienie oraz że fazowe uwalnianie dopaminy pośredniczy w pro- 

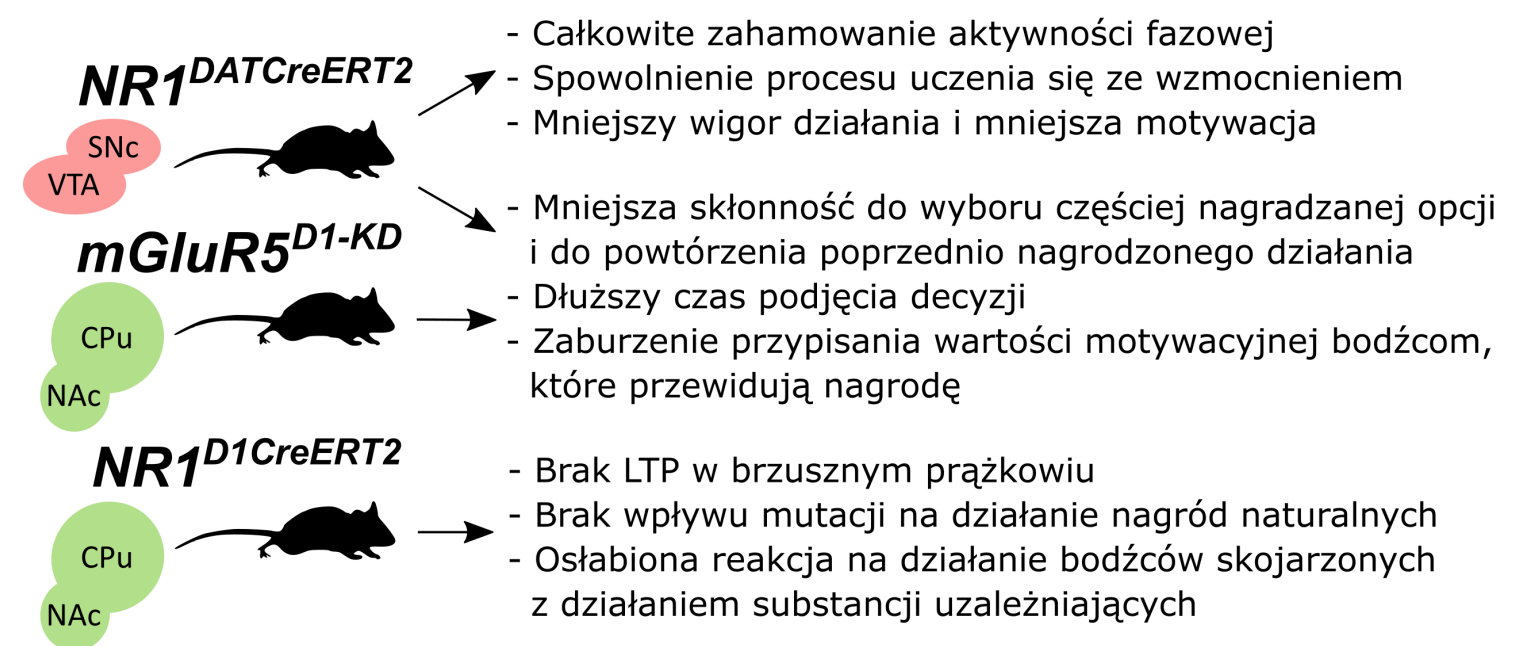

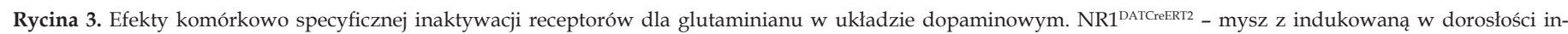

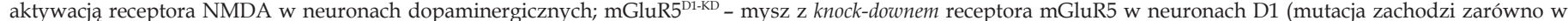

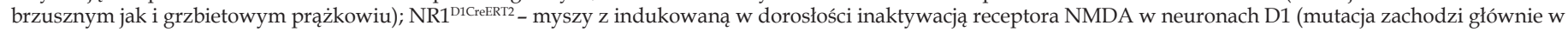
brzusznym prążkowiu).

cesie przypisania wartości motywacyjnej bodźcom skojarzonym z nagrodą $[65,91]$. W wyniku tego procesu, bodźce skojarzone z nagrodą mogą nasilać zachowanie poszukiwawcze. Brak nasilenia zachowania poszukiwawczego oraz brak reakcji warunkowego wzmocnienia u myszy z mutacją, sugeruje, że u tych zwierząt proces atrybucji znaczenia jest zaburzony. Oznacza to, że przekazywanie sygnału zależne od receptora NMDA w neuronach dopaminergicznych ma kluczowe znaczenie dla regulacji tego procesu.

W kontekście motywacji interesujące jest również to, że badania elektrochemiczne pokazują, iż moment inicjacji działania nakierowanego na pozyskanie nagrody poprzedzony jest wzrostem zewnątrzkomórkowego stężenia dopaminy w brzusznym prążkowiu, związanym z fazowym trybem uwalniania neuroprzekaźnika [31,49,50]. Inaktywacji receptorów NMDA w neuronach dopaminergicznych towarzyszy z kolei opóźnienie podjęcia działania [72,85]. Co więcej, myszy z indukowalnym wariantem mutacji charakteryzują się dłuższym czasem bezruchu w teście wymuszonego pływania i są mniej skłonne do wykonania działania, które wymaga wysiłku, aby zdobyć nagrodę, co kojarzone jest z rozwojem objawów przypominających depresję [77]. Zatem, zależna od receptora NMDA aktywność neuronów dopaminergicznych reguluje proces inicjacji działania oraz wydatkowania wysiłku, odpowiadając tym samym za aktywacyjny aspekt motywacji $[48,55]$.

Selektywna inaktywacja receptorów mGluR5 w neuronach prążkowia wyrażających ekspresję receptora D1 również prowadzi do zaburzenia procesu przypisania wartości motywacyjnej bodźcom skojarzonym z nagrodą i opóźnienia podjęcia działania $[83,85]$. U myszy pozbawionych receptorów NMDA, zaobserwowano zaburzenie procesu uczenia asocjacyjnego i uwarunkowanej odpowiedzi na bodziec skojarzony z nagrodą w przypadku zwierząt z konstytutywną mutacją [92], a u zwierząt $\mathrm{z}$ mutacją indukowaną w dorosłości wykazano z kolei, że bodźce powiązane z nagrodą naturalną wywołują normalną reakcję poszukiwania nagrody, natomiast w przypadku bodźców skojarzo- nych z działaniem substancji uzależniających reakcja ta jest osłabiona [82]. Może to oznaczać, że mechanizm działania nagród naturalnych i substancji uzależniających w różny sposób angażuje plastyczność zależną od receptora NMDA w neuronach dopaminoceptywnych. Tak czy inaczej, można przypuszczać, że w przypadku neuronów prążkowia transmisja zależna od glutaminianu również mediuje proces przypisania wartości motywacyjnej bodźcom skojarzonym $\mathrm{z}$ nagrodą.

\section{WNIOSKI}

Przytoczone badania, wykonane na zwierzętach z komórkowo specyficzną inaktywacją receptorów glutaminianu w układzie dopaminowym wykazały, że zaburzenie przekazywania sygnału zależnego od receptorów NMDA i mGluR5 w układzie dopaminowym prowadzi do nieprawidłowości w zakresie uczenia się ze wzmocnieniem oraz procesów motywacyjnych decydujących o szybkości podjęcia działania i jego wigorze (Ryc. 3). Zaburzenia motywacji i wrażliwości na działanie nagród stanowią często główną oś objawów towarzyszących chorobom psychicznym takim jak depresja, schizofrenia czy uzależnienia. Na podstawie omawianych w pracy wyników badań można wysunąć przypuszczenie, że mechanizmem leżącym u podłoża powstawania tych objawów mogą być zaburzenia w transmisji glutaminianergicznej, związanej z generowaniem aktywności fazowej neuronów dopaminergicznych i modulacją plastyczności neuronów dopaminoceptywnych. Oddziaływania farmakoterapeutyczne nakierowane na przywrócenie równowagi w zakresie przekazywania sygnału zależnego od receptorów dla glutaminianu w układzie dopaminowym mogłyby stanowić potencjalny cel terapii zaburzeń psychicznych.

\section{PIŚMIENNICTWO}

1. Björklund A, Dunnett SB (2007) Dopamine neuron systems in the brain: an update. Trends Neurosci 30: 194-202

2. Morales M, Margolis EB (2017) Ventral tegmental area: cellular heterogeneity, connectivity and behaviour. Nat Rev Neurosci 18: 73-85 
3. Witten IB, Steinberg EE, Lee SY, Davidson TJ, Zalocusky KA, Brodsky M, Yizhar O, Cho SL, Gong S, Ramakrishnan C, Stuber GD, Tye KM, Janak PH, Deisseroth K (2011) Recombinase-driver rat lines: tools, techniques, and optogenetic application to dopamine-mediated reinforcement. Neuron 72: 721-733

4. Lammel S, Steinberg EE, Földy C, Wall NR, Beier K, Luo L, Malenka RC (2015) Diversity of transgenic mouse models for selective targeting of midbrain dopamine neurons. Neuron 85: 429-438

5. Dahlström A, Fuxe K (1964) Evidence for the existence of monoamine-containing neurons in the central nervous system. I. Demonstration of monoamines in the cell bodies of brain stem neurons. Acta Physiol Scand Suppl:SUPPL 232: 1-55

6. Haber SN (2014) The place of dopamine in the cortico-basal ganglia circuit. Neuroscience 282: 248-257

7. Ikemoto S (2007) Dopamine reward circuitry: two projection systems from the ventral midbrain to the nucleus accumbens-olfactory tubercle complex. Brain Res Rev 56: 27-78

8. Schultz W (1998) Predictive reward signal of dopamine neurons. J Neurophysiol 80: 1-27

9. Lammel S, Lim BK, Malenka RC (2014) Reward and aversion in a heterogeneous midbrain dopamine system. Neuropharmacology $76 \mathrm{Pt}$ B: $351-359$

10. Roeper J (2013) Dissecting the diversity of midbrain dopamine neurons. Trends Neurosci 36:336-342

11. Paladini CA, Roeper J (2014) Generating bursts (and pauses) in the dopamine midbrain neurons. Neuroscience 282: 109-121

12. Wightman RM, Robinson DL (2002) Transient changes in mesolimbic dopamine and their association with "reward." J Neurochem 82: 721-735

13. Floresco SB, West AR, Ash B, Moore H, Grace AA (2003) Afferent modulation of dopamine neuron firing differentially regulates tonic and phasic dopamine transmission. Nat Neurosci 6: 968-973

14. Lodge DJ, Grace AA (2006) The laterodorsal tegmentum is essential for burst firing of ventral tegmental area dopamine neurons. Proc Natl Acad Sci USA 103: 5167-5172

15. Grace AA, Floresco SB, Goto Y, Lodge DJ (2007) Regulation of firing of dopaminergic neurons and control of goal-directed behaviors. Trends Neurosci 30: 220-227

16. Glimcher PW (2011) Understanding dopamine and reinforcement learning: the dopamine reward prediction error hypothesis. Proc Natl Acad Sci USA 108 Suppl 3: 15647-15654

17. Neve KA, Seamans JK, Trantham-Davidson H (2004) Dopamine receptor signaling. J Recept Signal Transduct Res 24: 165-205

18. Dreyer JK, Herrik KF, Berg RW, Hounsgaard JD (2010) Influence of phasic and tonic dopamine release on receptor activation. J Neurosci 30: 14273-14283

19. Goto Y, Otani S, Grace AA (2007) The Yin and Yang of dopamine release: a new perspective. Neuropharmacology 53: 583-587

20. Dudman JT, Gerfen CR (2015) The Basal Ganglia. W: Paxinos G (red) The Rat Nervous System $4^{\text {th }}$ edition, str. 391-440

21. Gerfen CR, Surmeier DJ (2011) Modulation of striatal projection systems by dopamine. Annu Rev Neurosci 34: 441-466

22. Gerfen CR, Engber TM, Mahan LC, Susel Z, Chase TN, Monsma FJ, Sibley DR (1990) D1 and D2 dopamine receptor-regulated gene expression of striatonigral and striatopallidal neurons. Science 250: 1429-1432

23. Surmeier DJ, Song WJ, Yan Z (1996) Coordinated expression of dopamine receptors in neostriatal medium spiny neurons. J Neurosci 16: 6579-6591

24. Valjent E, Bertran-Gonzalez J, Hervé D, Fisone G, Girault J-A (2009) Looking BAC at striatal signaling: cell-specific analysis in new transgenic mice. Trends Neurosci 32: 538-547

25. Kravitz AV, Tye LD, Kreitzer AC (2012) Distinct roles for direct and indirect pathway striatal neurons in reinforcement. Nat Neurosci 15: 816-818
26. Tai L-H, Lee AM, Benavidez N, Bonci A, Wilbrecht L (2012) Transient stimulation of distinct subpopulations of striatal neurons mimics changes in action value. Nat Neurosci 15: 1281-1289

27. Montague PR, Dayan P, Sejnowski TJ (1996) A framework for mesencephalic dopamine systems based on predictive Hebbian learning. J Neurosci 16: 1936-1947

28. Schultz W, Dayan P, Montague PR (1997) A neural substrate of prediction and reward. Science 275: 1593-1599

29. Fiorillo CD, Tobler PN, Schultz W (2003) Discrete coding of reward probability and uncertainty by dopamine neurons. Science 299: 1898 1902

30. Tobler PN, Fiorillo CD, Schultz W (2005) Adaptive coding of reward value by dopamine neurons. Science 307: 1642-1645

31. Phillips PEM, Stuber GD, Heien MLAV, Wightman RM, Carelli RM (2003) Subsecond dopamine release promotes cocaine seeking. Nature 422: 614-618

32. Adamantidis AR, Tsai H-C, Boutrel B, Zhang F, Stuber GD, Budygin EA, Touriño C, Bonci A, Deisseroth K, de Lecea L (2011) Optogenetic interrogation of dopaminergic modulation of the multiple phases of reward-seeking behavior. J Neurosci 31: 10829-10835

33. Ilango A, Kesner AJ, Keller KL, Stuber GD, Bonci A, Ikemoto S (2014) Similar roles of substantia nigra and ventral tegmental dopamine neurons in reward and aversion. J Neurosci 34: 817-822

34. Calabresi P, Picconi B, Tozzi A, Di Filippo M (2007) Dopamine-mediated regulation of corticostriatal synaptic plasticity. Trends Neurosci 30: 211-219

35. Surmeier DJ, Plotkin J, Shen W (2009) Dopamine and synaptic plasticity in dorsal striatal circuits controlling action selection. Curr Opin Neurobiol 19: 621-628

36. Wickens JR (2009) Synaptic plasticity in the basal ganglia. Behav Brain Res 199: 119-128

37. Lee D, Seo H, Jung MW (2012) Neural basis of reinforcement learning and decision making. Annu Rev Neurosci 35: 287-308

38. Samejima K, Ueda Y, Doya K, Kimura M (2005) Representation of action-specific reward values in the striatum. Science 310: 1337-1340

39. D'Ardenne K, McClure SM, Nystrom LE, Cohen JD (2008) BOLD responses reflecting dopaminergic signals in the human ventral tegmental area. Science 319: 1264-1267

40. Knutson B, Taylor J, Kaufman M, Peterson R, Glover G (2005) Distributed neural representation of expected value. J Neurosci 25: 4806-4812

41. O’Doherty J, Dayan P, Schultz J, Deichmann R, Friston K, Dolan RJ (2004) Dissociable roles of ventral and dorsal striatum in instrumental conditioning. Science 304: 452-454

42. Pessiglione M, Seymour B, Flandin G, Dolan RJ, Frith CD (2006) Dopamine-dependent prediction errors underpin reward-seeking behaviour in humans. Nature 442: 1042-1045

43. Rutledge RB, Dean M, Caplin A, Glimcher PW (2010) Testing the reward prediction error hypothesis with an axiomatic model. J Neurosci 30: 13525-13536

44. Frank MJ, Seeberger LC, O'reilly RC (2004) By carrot or by stick: cognitive reinforcement learning in parkinsonism. Science 306: 1940-1943

45. Rutledge RB, Lazzaro SC, Lau B, Myers CE, Gluck MA, Glimcher PW (2009) Dopaminergic drugs modulate learning rates and perseveration in Parkinson's patients in a dynamic foraging task. J Neurosci 29: 15104-15114

46. Heinz A, Schlagenhauf F, Beck A, Wackerhagen C (2016) Dimensional psychiatry: mental disorders as dysfunctions of basic learning mechanisms. J Neural Transm (Vienna) 123: 809-821

47. Whitton AE, Treadway MT, Pizzagalli DA (2015) Reward processing dysfunction in major depression, bipolar disorder and schizophrenia. Curr Opin Psychiatry 28: 7-12

48. Salamone JD, Correa M (2012) The mysterious motivational functions of mesolimbic dopamine. Neuron 76: 470-485

49. Roitman MF, Stuber GD, Phillips PEM, Wightman RM, Carelli RM (2004) Dopamine operates as a subsecond modulator of food seeking. J Neurosci 24: 1265-1271 
50. Syed ECJ, Grima LL, Magill PJ, Bogacz R, Brown P, Walton ME (2016) Action initiation shapes mesolimbic dopamine encoding of future rewards. Nat Neurosci 19: 34-36

51. Ko D, Wanat MJ (2016) Phasic Dopamine Transmission Reflects Initiation Vigor and Exerted Effort in an Action- and Region-Specific Manner. J Neurosci 36: 2202-2211

52. Floresco SB, Tse MTL, Ghods-Sharifi S (2008) Dopaminergic and glutamatergic regulation of effort- and delay-based decision making. Neuropsychopharmacology 33: 1966-1979

53. Nicola SM (2010) The flexible approach hypothesis: unification of effort and cue-responding hypotheses for the role of nucleus accumbens dopamine in the activation of reward-seeking behavior. J Neurosci 30: 16585-16600

54. Salamone JD, Wisniecki A, Carlson BB, Correa M (2001) Nucleus accumbens dopamine depletions make animals highly sensitive to high fixed ratio requirements but do not impair primary food reinforcement. Neuroscience 105: 863-870

55. Salamone JD, Yohn SE, López-Cruz L, San Miguel N, Correa M (2016) Activational and effort-related aspects of motivation: neural mechanisms and implications for psychopathology. Brain 139: 1325-1347

56. Croxson PL, Walton ME, O'Reilly JX, Behrens TEJ, Rushworth MFS (2009) Effort-based cost-benefit valuation and the human brain. J Neurosci 29: 4531-4541

57. Kroemer NB, Guevara A, Ciocanea Teodorescu I, Wuttig F, Kobiella A, Smolka MN (2014) Balancing reward and work: anticipatory brain activation in NAcc and VTA predict effort differentially. Neuroimage 102 Pt 2: 510-519

58. Treadway MT, Buckholtz JW, Cowan RL, Woodward ND, Li R, Ansari MS, Baldwin RM, Schwartzman AN, Kessler RM, Zald DH (2012b) Dopaminergic mechanisms of individual differences in human effort-based decision-making. J Neurosci 32: 6170-6176

59. Beierholm U, Guitart-Masip M, Economides M, Chowdhury R, Düzel E, Dolan R, Dayan P (2013) Dopamine modulates reward-related vigor. Neuropsychopharmacology 38: 1495-1503

60. Guitart-Masip M, Chowdhury R, Sharot T, Dayan P, Duzel E, Dolan RJ (2012) Action controls dopaminergic enhancement of reward representations. Proc Natl Acad Sci USA 109: 7511-7516

61. Chong TT-J, Bonnelle V, Manohar S, Veromann K-R, Muhammed K, Tofaris GK, Hu M, Husain M (2015) Dopamine enhances willingness to exert effort for reward in Parkinson's disease. Cortex 69: 40-46

62. Treadway MT, Bossaller NA, Shelton RC, Zald DH (2012a) Effort-based decision-making in major depressive disorder: A translational model of motivational anhedonia. Journal of Abnormal Psychology 121: 553-558

63. Berridge KC (2007) The debate over dopamine's role in reward: the case for incentive salience. Psychopharmacology (Berl) 191: 391-431

64. Berridge KC, Robinson TE (1998) What is the role of dopamine in reward: hedonic impact, reward learning, or incentive salience? Brain Res Brain Res Rev 28: 309-369

65. Flagel SB, Clark JJ, Robinson TE, Mayo L, Czuj A, Willuhn I, Akers CA, Clinton SM, Phillips PEM, Akil H (2011) A selective role for dopamine in stimulus-reward learning. Nature 469: 53-57

66. Saunders BT, Robinson TE (2012) The role of dopamine in the accumbens core in the expression of Pavlovian-conditioned responses. Eur J Neurosci 36: 2521-2532

67. Hyland BI, Reynolds JNJ, Hay J, Perk CG, Miller R (2002) Firing modes of midbrain dopamine cells in the freely moving rat. Neuroscience 114: 475-492

68. Chergui K, Charléty PJ, Akaoka H, Saunier CF, Brunet JL, Buda M, Svensson TH, Chouvet G (1993) Tonic activation of NMDA receptors causes spontaneous burst discharge of rat midbrain dopamine neurons in vivo. Eur J Neurosci 5: 137-144

69. Overton P, Clark D (1992) Iontophoretically administered drugs acting at the N-methyl-D-aspartate receptor modulate burst firing in A9 dopamine neurons in the rat. Synapse 10: 131-140
70. Sombers LA, Beyene M, Carelli RM, Wightman RM (2009) Synaptic overflow of dopamine in the nucleus accumbens arises from neuronal activity in the ventral tegmental area. J Neurosci 29: 1735-1742

71. Wickham R, Solecki W, Rathbun L, McIntosh JM, Addy NA (2013) Ventral tegmental area a $6 \beta 2$ nicotinic acetylcholine receptors modulate phasic dopamine release in the nucleus accumbens core. Psychopharmacology (Berl) 229: 73-82

72. Zweifel LS, Parker JG, Lobb CJ, Rainwater A, Wall VZ, Fadok JP, Darvas M, Kim MJ, Mizumori SJY, Paladini CA, Phillips PEM, Palmiter RD (2009) Disruption of NMDAR-dependent burst firing by dopamine neurons provides selective assessment of phasic dopamine-dependent behavior. Proc Natl Acad Sci USA 106: 7281-7288

73. Parker JG, Zweifel LS, Clark JJ, Evans SB, Phillips PEM, Palmiter RD (2010) Absence of NMDA receptors in dopamine neurons attenuates dopamine release but not conditioned approach during Pavlovian conditioning. Proc Natl Acad Sci USA 107: 13491-13496

74. Wang LP, Li F, Wang D, Xie K, Wang D, Shen X, Tsien JZ (2011) NMDA receptors in dopaminergic neurons are crucial for habit learning. Neuron 72: 1055-1066

75. Engblom D, Bilbao A, Sanchis-Segura C, Dahan L, Perreau-Lenz S, Balland B, Rodriguez Parkitna J, Luján R, Halbout B, Mameli M, Parlato R, Sprengel R, Lüscher C, Schütz G, Spanagel R (2008) Glutamate receptors on dopamine neurons control the persistence of cocaine seeking. Neuron 59: 497-508

76. Zweifel LS, Argilli E, Bonci A, Palmiter RD (2008) Role of NMDA receptors in dopamine neurons for plasticity and addictive behaviors. Neuron 59: 486-496

77. Jastrzębska K, Walczak M, Cieślak PE, Szumiec Ł, Turbasa M, Engblom D, Błasiak T, Rodriguez Parkitna J (2016) Loss of NMDA receptors in dopamine neurons leads to the development of affective disorder-like symptoms in mice. Sci Rep 6:37171.

78. Shen W, Flajolet M, Greengard P, Surmeier DJ (2008) Dichotomous dopaminergic control of striatal synaptic plasticity. Science 321:848-851.

79. Yagishita S, Hayashi-Takagi A, Ellis-Davies GCR, Urakubo H, Ishii S, Kasai H (2014) A critical time window for dopamine actions on the structural plasticity of dendritic spines. Science 345:1616-1620.

80. Beutler LR, Eldred KC, Quintana A, Keene CD, Rose SE, Postupna N, Montine TJ, Palmiter RD (2011) Severely impaired learning and altered neuronal morphology in mice lacking NMDA receptors in medium spiny neurons. PLoS ONE 6:e28168.

81. Ohtsuka N, Tansky MF, Kuang H, Kourrich S, Thomas MJ, Rubenstein JLR, Ekker M, Leeman SE, Tsien JZ (2008) Functional disturbances in the striatum by region-specific ablation of NMDA receptors. Proc Natl Acad Sci USA 105:12961-12966.

82. Sikora M, Tokarski K, Bobula B, Zajdel J, Jastrzębska K, Cieślak PE, Zygmunt M, Sowa J, Smutek M, Kamińska K, Gołembiowska K, Engblom D, Hess G, Przewlocki R, Rodriguez Parkitna J (2016) NMDA Receptors on Dopaminoceptive Neurons Are Essential for Drug-Induced Conditioned Place Preference. eNeuro 3:ENEURO.0084-15.2016.

83. Novak M, Halbout B, O'Connor EC, Rodriguez Parkitna J, Su T, Chai M, Crombag HS, Bilbao A, Spanagel R, Stephens DN, Schütz G, Engblom D (2010) Incentive learning underlying cocaine-seeking requires mGluR5 receptors located on dopamine D1 receptor-expressing neurons. J Neurosci 30:11973-11982.

84. Rodriguez Parkitna J, Sikora M, Gołda S, Gołembiowska K, Bystrowska B, Engblom D, Bilbao A, Przewlocki R (2013) Novelty-seeking behaviors and the escalation of alcohol drinking after abstinence in mice are controlled by metabotropic glutamate receptor 5 on neurons expressing dopamine d1 receptors. Biol Psychiatry 73:263-270.

85. Cieślak PE, Ahn WY, Bogacz R, Rodriguez Parkitna J (2018) Selective effects of the loss of NMDA or mGluR5 receptors in the reward system on adaptive decision-making. eNeuro 5:ENEURO.0331-18.2018.

86. James AS, Pennington ZT, Tran P, Jentsch JD (2015) Compromised NMDA/Glutamate Receptor Expression in Dopaminergic Neurons Impairs Instrumental Learning, But Not Pavlovian Goal Tracking or Sign Tracking. eNeuro 2:ENEURO.0040-14.2015 
87. Yin HH, Knowlton BJ, Balleine BW (2005) Blockade of NMDA receptors in the dorsomedial striatum prevents action-outcome learning in instrumental conditioning. Eur J Neurosci 22: 505-512

88. Balleine BW, Delgado MR, Hikosaka O (2007) The role of the dorsal striatum in reward and decision-making. J Neurosci 27: 8161-8165

89. Yin HH, Ostlund SB, Balleine BW (2008) Reward-guided learning beyond dopamine in the nucleus accumbens: the integrative functions of cortico-basal ganglia networks. Eur J Neurosci 28: 1437-1448

90. Cieślak PE, Rodriguez Parkitna J (2019) Ablation of NMDA receptors in dopamine neurons disrupts attribution of incentive salience to reward paired stimuli. Behav Brain Res 363: 77-82
91. Wickham RJ, Solecki WB, Nunes EJ, Addy NA (2015) Distinct effects of ventral tegmental area NMDA and acetylcholine receptor blockade on conditioned reinforcement produced by food-associated cues. Neuroscience 301: 384-394

92. Parker JG, Beutler LR, Palmiter RD (2011) The contribution of NMDA receptor signaling in the corticobasal ganglia reward network to appetitive Pavlovian learning. J Neurosci 31: 11362-11369

\section{Glutamate receptors in the dopamine system - function and role in reinforcement learning}

\section{Przemysław Eligiusz Cieślak ${ }^{\varpi}$}

Department of Neurophysiology and Chronobiology, Institute of Zoology and Biomedical Research, Jagiellonian University, Krakow

$\unrhd^{\natural}$ Corresponding Author: pe.cieslak@uj.edu.pl

Key words: dopamine, NMDA receptor, mGluR5 receptor, reinforcement learning, motivation

\section{ABSTRACT}

Midbrain dopamine neurons along with the major target of their projections, dopaminoceptive neurons in striatum, regulate reinforcement learning and motivation. The activity and plasticity in the dopamine system are largely dependent on excitatory glutamatergic transmission. The article describes the functional role of N-methyl-D-aspartate (NMDA) receptors in driving the phasic activity in dopamine neurons, and a role of NMDA and metabotropic glutamate 5 (mGluR5) receptors in induction of plasticity in dopaminoceptive striatal medium spiny neurons. Based on published studies on genetically modified mice, the article further discusses how targeted loss of glutamate receptor-dependent signalling in dopamine system affects reinforcement learning and motivational processes. The conclusion of the article is the view that aberrant glutamate signalling in dopamine system may contribute to maladaptive behaviours, which are particularly often observed in mental disorders.

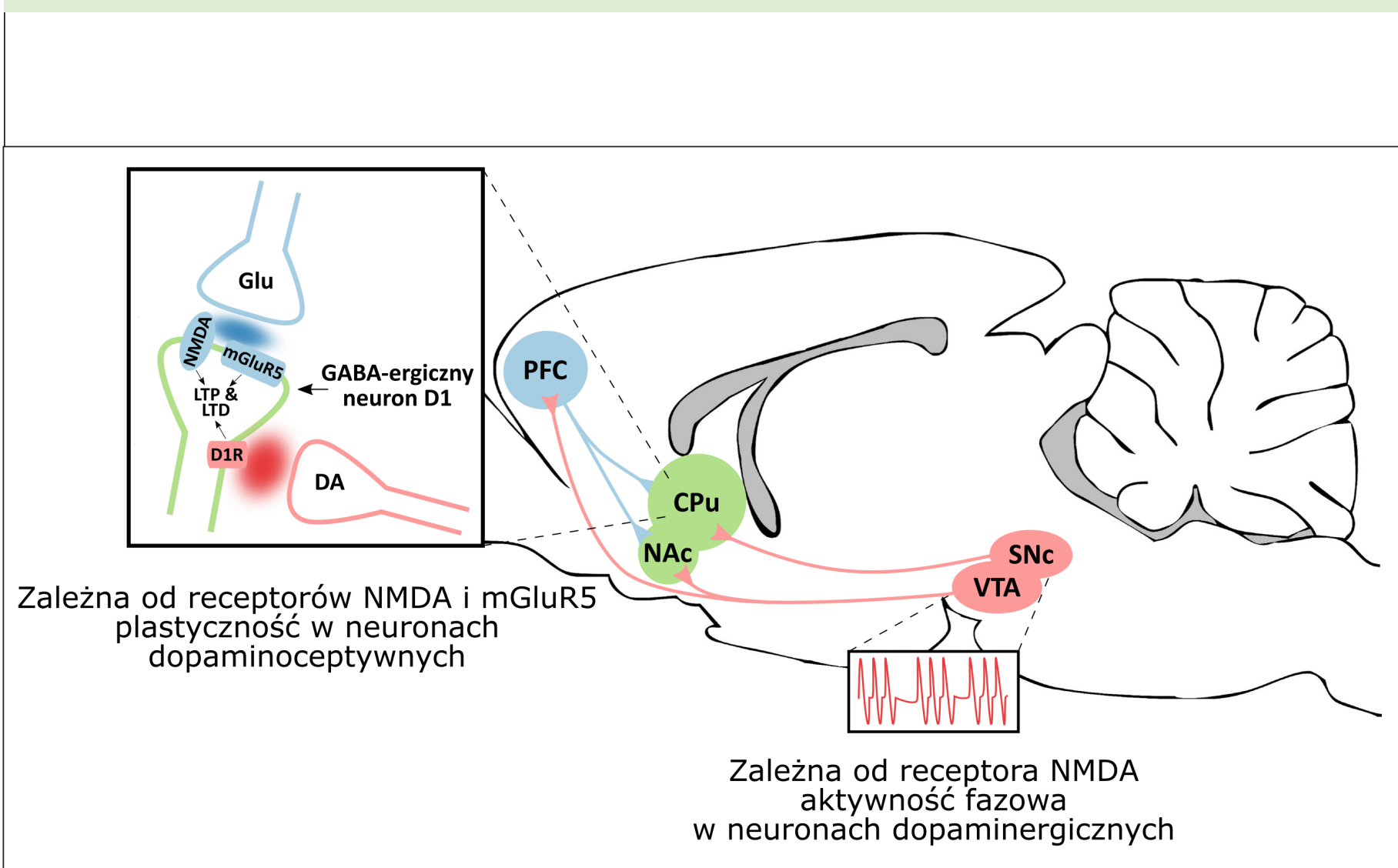

